\title{
Making Work Volition to Predict Job Satisfaction of Faculty Members in Higher Educational Institutes
}

\author{
Jagannath Mohanty'1, Alamzeb Aamir ${ }^{2}$ \\ ${ }^{1}$ Institute of Management Technology, Nagpur, India \\ ${ }^{2}$ King Saud University, Riyadh, KSA \\ Email: jagmohanty@rediffmail.com, aamir@ksu.sa.in
}

How to cite this paper: Mohanty, J. and Aamir, A. (2018) Making Work Volition to Predict Job Satisfaction of Faculty Members in Higher Educational Institutes. Theoretical Economics Letters, 8, 1427-1442. https://doi.org/10.4236/tel.2018.87092

Received: April 19, 2018

Accepted: May 29, 2018

Published: June 1, 2018

Copyright (c) 2018 by authors and Scientific Research Publishing Inc. This work is licensed under the Creative Commons Attribution International License (CC BY 4.0).

http://creativecommons.org/licenses/by/4.0/

\section{(c) (i) Open Access}

\begin{abstract}
Academic literature on business management indicates employee job satisfaction as a key workplace factor. Increased productivity is often construed as a dividend accruing from job satisfaction. Therefore, organizations strive hard through organizational policies and processes to ensure employees are satisfied with their jobs. Work volition is generally understood as the degree of freedom organizationally available to choose a job profile. This paper explores the role of work volition in job satisfaction. It is assumed that chosen work roles catalyze the process of job satisfaction. The paper factors in internal and external job satisfaction as contributors to overall job satisfaction. The results from this work reported a significant impact of work volition on both internal and external satisfaction.
\end{abstract}

\section{Keywords}

Higher Education Sector, Work Volition, Job Satisfaction

\section{Introduction}

A considerable amount of effort goes into finding the right job for individuals during and after formal education. As a matter of fact, several studies in the past have pointed out that only a minority of individuals work to achieve intrinsic objectives. However, majority of people work for survival needs [1]. This proposition diverges from previous career theories that not all individuals are able to acquire work that matches their idealized visions of a career [2]. Instead, many people experience career constraints that limit their volition to achieve employment that aims higher level needs. According to the Psychology of Working 
Framework by Blustein [1], majority of individuals do not have complete freedom of choice in their career decision making herein referred to as work volition. A number of studies have demonstrated that people derive professional satisfaction from self-chosen jobs over those forced upon due to compelling employment reasons. However, Blustein [1] presented a construct critical to understanding the career trajectory of those who face a spectrum of work-related barriers throughout their career paths.

The employee job satisfaction or motivation is a subject that is widely discussed by researchers from time to time. A variety of the researchers agree on factors leading to job satisfaction and employee motivation. Recently, Duffy et al., [3] highlighted the predictors of job satisfaction. The highlighted factors were "self-efficacy, personality, organizational support, core self-evaluations, person environment fit, and goal behavior". Similarly, they further added that although previous studies were able to highlight various variables, these studies focused only on one segment of population educated and having access to finances and opportunities. These studies ignored population with limited opportunities and financially deprived. The present study is an attempt to answer the call of Duffy et al., [4] to examine "what makes people happy at work".

\section{The Concept of Work Volition}

Work volition is defined as one's perceived freedom of future work choice despite constraints [3] [4]. It is defined as the perceived capacity to make occupational decisions (or in the case of college students future occupational decisions) despite constraints. The construct is distinct from the related adaptability construct of control because it explicitly measures the perception of control in career decision making, versus overall career development. Similar to a general sense of control, work volition represents the feelings of control, however, these feelings are specific to the domain of career decision making.

Since 1970s, the researchers are focused on the volition in the field of temporary employment [5]. In the recent studies the volition is linked with many positive psychological phenomenon [6] [7] [8]. Volition induces the perception of choice and control, where these may promote positive attitudes, psychological well-being, and constructive behaviour [6] [7]. Holtom, Lee, and Tidd [8] argued that volition is useful in reducing the discrepancy between one's desired and actual job. Feldman and Turnley, [9] considered work volition may prevent the development of feelings of relative deprivation in the employees. However, the researchers agree that work volition operate on a continuum, and change across the life span due to life circumstances [1] [4].

Recent studies have shown lack of education, poverty, mental or physical disabilities, family pressures, and discrimination are some of the potential barriers that are likely to constrain an individual's ability to freely pursue a specific career [1] [2]. Instead of assessing all the potential barriers that individuals may face in the pursuit of a specific career, measuring work volition encapsulates an 
individual's overall perception of choice in relation to occupational decisions.

From the recent studies on work volition, it can be concluded that individuals are likely to have a unique sense of constraints to their career decision making, and even those without clearly evident barriers may still feel limited in the careers they feel they can pursue work volition scores have been found to negatively correlate with racial discrimination, sex discrimination, and overall career barriers [3] [4]. An analogous correlation between work volition and career barriers was found in the development of work volition scale [4]. Other research studies both on student and adult populations have shown that work volition moderately to strongly correlates with CDSE, domain self-efficacy, career adaptability, academic satisfaction, job satisfaction, and life satisfaction [3] [4] [10] [11]. Clearly, work volition is an important construct, yet the examination of how predictors of this construct function concurrently or relate to work volition over time is almost entirely absent.

\section{Job Satisfaction}

Numerous attempts in the past have been made to define and describe job satisfaction [12] [13]. Few notable efforts in this regard are that of Locke [14] Armstrong [15] and Odom et al., [16]. The earliest attempt to define job satisfaction was made by Locke [14], who mentioned job satisfaction as being any number of psychological, physiological and environmental circumstances which lead an individual to express his/her satisfaction with their work. Odom et al., [16] on the other hand, described job satisfaction as the employees' general affective assessment of their job and the degree to which an employee feels positively or negatively about his or her job. Similarly, [15] Armstrong referred to job satisfaction as the employee's feeling and attitude. Ranft and Ranft [17] added to the debate by mentioning that job satisfaction is the combination of an employee's attitude toward or about the job. This attitude is at times referred to as a "positive element" [18], which leads to effective employee's performance, and makes them less likely to leave the organization [19].

Research conducted by Tourangeau and Cranley, [20] confirmed the importance of job satisfaction, and its relationship with employee's retention within organization. Review of previous studies highlighted that job satisfaction and the intent to leave organization depends upon various factors which include pay, work schedule, promotional opportunities, co-workers support, and supervision [21] [22] [23] are correlated, but job satisfaction does not guarantee overall satisfaction.

Generally, job satisfaction can be divided into two different types' i.e. extrinsic job satisfaction and intrinsic job satisfaction [24]. Extrinsic job satisfaction refers to tangible aspects of job and linked with external sources for employees, for example, pay, co-workers, retirement, health insurance benefits and supervision. Whereas, Intrinsic job satisfaction is linked with internal sources, for example, job complexity, amount of responsibility, skill utilization, being able to help oth- 
ers, enjoying one's tasks and challenges [25] [26].

Similarly, the previous meta-analytic studies focusing on job satisfaction showed that personal variables generally had low correlation with job satisfaction [27]. Whereas, job-related perceptions such as task identity, task significance and autonomy had positive correlations with job satisfaction [26]. However, the employee's lack of satisfaction not only has a negative impact on job performance and success, but also results in increased absenteeism, decreased productivity and separation from the job [28]. Number of studies have examined the relationship between job satisfaction and turnover and reported a negative relationship, implying less satisfied employees are likely to leave the organization [29] [30] [31] [32] [33]. Similarly study by Vandenberg and Nelson [34] contended that most turnovers in organizations arise from lack of satisfaction, and satisfaction could lead to higher productivity [35].

Herzberg et al. [36] was of the view that job satisfaction and dissatisfaction depend on diverse sets of job related to situations and are affected by different job related factors [37]. Greenberg [38] and Ellickson and Logsdon [39] both reported that career development, promotional opportunities, responsibility, career advancement, recognition, and achievements are all potential motivators that may directly impact employee job satisfaction.

It is significant to know the conventional ideas of job satisfaction at the time Herzberg et al. [36] proposed his theory of satisfaction and dissatisfaction were measured as extremes on a single scale with a neutral condition in the midpoint in which individual is neither satisfied nor dissatisfied [40]. Workers shift along this singular scale as factors are changed or introduced. So, organizations mainly focused on hygiene factors in an effort to improve output. Herzberg et al. [36] argued that this approach was flawed. He suggested that in order to increase satisfaction, the factors of motivation must also be improved. Similarly Herzberg et al., [36], argued that jobs should be restructured to increase the ability of the employees to accomplish goals that are meaningfully linked to the doing of job. Job satisfaction can also be reached by matching the individual's work capacity to the work he will need to do during the selection process. He also proposed increased role of the supervisor in job satisfaction, managers should provide recognition when needed and effectively plan and organize the work.

Though widely used, Herzberg's [36] theory has been criticized by several scholars. Shields [41] criticized the theory on the ground that people normally blame others for any issues and portray self as the reason behind the success story. Similarly, Gaziel [42] criticized the theory on the following grounds: 1) sources of satisfaction and dissatisfaction are overlapped; 2 ) the theory confuses events instigating feelings of satisfaction and dissatisfaction with the agent that triggered the event to happen; 3) the importance of the factors varied as a function of the employee's job level; 4) the theory seems to be bound to the critical event method; 5) the theory overlooks the part played by individual employees differences; and 6) the consistency of the data could have been negatively im- 
movable by ego-defensiveness on the part of the employee.

\section{Job Satisfaction in Educators}

Studies on job satisfaction amongst the faculty member highlighted the complex nature of the phenomenon [43]. The complexity arises as a result of the diversified background of the faculty members that makes identification of their satisfaction level difficult [44]. Researchers are of the view that higher education institutes are not an exception to the problem of job satisfaction; in fact, educational leaders have increased their focus on the studies to identify factors that affect job satisfaction of employees at different levels [45]. Previously, the focus of research studies on job satisfaction was primarily on the industrial sector [44]. This trend of industry focused studies could be judged by the fact that until 1992 only $13.7 \%$ of total studies was carried out on faculty job satisfaction [44]. Attempts in the past were made to recognize specific variables and relationship of these variables to faculty job satisfaction [46] [47]. These factors may range from organizational support and personal support to overall compensation packages [48]. In a different but contrasting study Hagedorn [49] formulated her theoretical frame work about job satisfaction by using two divisions between job satisfaction perspectives, which she termed as triggers and mediators.

Similarly, the cross-national study of faculty from 16 different countries, found different variables and ranked them as important factors for faculty job satisfaction: pay, career development opportunities, institutional affiliation, level of job pressure, geographic location and locus of control. And also observed that other factors i.e. instruction as a primary role, courses taught, institutional facilities, and quality of retirement benefits did not predict faculty job satisfaction [47].

\section{Impact of Work Volition on Job Satisfaction}

The decision of an individual about job depends on various factors, one such factor relates to their ability to make decisions. Researchers for instance revealed that such decision making, which is based on "internal motivation" is known as volition [3]. Similarly, when decision making about job is concerned it lies within the domain of work volition. Duffy et al. [4] describe work volition as "the perceived capacity to make occupational choices despite constraints". They described work volition by using two lenses that is high work volition and low work volition. Review of recent literature, however shows the focus of researchers to use concept of volition to judge the level of employees' satisfaction. $\mathrm{Nu}$ merous researchers, have linked low work volition with low job satisfaction [7] [8] [9].

Leading researchers on work volition agree on the notion that individual decision about job is based on their "skills, values, and interest" [1] [2]. Duffy et al., [10] in a recent work raised the question about the scope of the above argument. They argued that the existence of constraints limits the ability of individuals to 
be volitional in their decision making. The constraints they mentioned ranged from financial limitations to physical \& cognitive to social limitations.

Recently, Jadidian and Duffy [50] pointed towards the limited research conducted in the area of work volition. They mentioned that although research was conducted in the past that were limited only to those variables that were similar to work volition. For instance, the variables that were previously focused largely include "sense of control" and "perception of barriers". A notable effort on work volition was made by Duffy, Diemer, and Jadidian [3] who developed a scale to measure work volition. In order to develop the scale Dufffy et al., [4] used two perspectives i.e. volition and constraints. For constraints they used financial constraints and structural constraints. Review of previous literature help identify regular discussion about several concepts which are similar to work volition [3] [4]. These include sense of control, perception of barriers, career barriers of control, career locus of control [3] [4].

\section{Research Objective}

This study aims at exploring the consequences of consciously chosen careers on job satisfaction levels among educators, particularly among those having taken to academics out of volition. Following are the research questions:

1) There shall be a positive correlation between work volition and job satisfaction.

2) Suitable career choice can predict job satisfaction levels.

\section{The Method}

The study employed quantitative research design. The unit of analysis for the current study was individuals working in the higher education sector in Pakis$\tan$. The key respondents in this study were the academic staffs of the HEIs (Higher Education Institutions) of Pakistan. The primary objective of this study is to investigate the impact of work volition on job satisfaction of employees in higher education institutions in Pakistan.

Data was collected from different regions. The population consisted of HEC (Higher Education Commission) recognized public and private higher education institutes of Pakistan. There are 160 HEC recognized HEIs out of which 90 are public, and the rest are private.

A proportionate random sampling technique was applied for the selection of Higher Educational Institutes. Sixteen Higher Educational Institutes comprised of 9 public and 7 private institutes. Sampling plans for HEIs are illustrated in Table 1.

A random sample of 320 faculty members (Lecturers, Assistant Professors, Associate Professors and Professors) recognized by HEC (Pakistan) were the participants in this study. Twenty questionnaires were administered in each of the selected universities. The data was collected from HEIs of the Federal, Punjab, Sindh and KPK province based on the proportionate sampling. From each 
Table 1. Sampling plan for public sector HEIs.

\begin{tabular}{ccccc}
\hline Region & Total number of HEIs & $\begin{array}{c}\text { Percentage to the } \\
\text { population }\end{array}$ & $\begin{array}{c}\text { Sample size } \\
\text { (HEIs) }\end{array}$ & Total respondents \\
\hline Capital & 24 & $27 \%$ & 2 & 40 \\
Punjab & 20 & $22 \%$ & 2 & 40 \\
Sindh & 17 & $19 \%$ & 2 & 40 \\
KPK & 19 & $21 \%$ & 2 & 40 \\
Baluchistan & 6 & $7 \%$ & 1 & 20 \\
AJK & 4 & $4 \%$ & 0 & 0 \\
TOTAL & 90 & $100 \%$ & 9 & 180 \\
\hline
\end{tabular}

Source: Compiled by the author from https://www.timeshighereducation.com.

institution researcher selected randomly 20 academic employees. This ensured a proportionate random sample as the number of institutions in Punjab is higher as compared to other provinces. Similarly the highest number of private HEIs is in Sindh region. Thus highest sample of the respondents were selected from the Sindh province. A total of 60 respondents from private HEIs of the Sindh province were selected.

To measure the job satisfaction of the academicians, the short form of the Minnesota Satisfaction Questionnaire [51] was adopted for the present study. The Minnesota Satisfaction Questionnaire (MSQ) is one of the most widely used instruments in the measurement of job satisfaction and its validity and reliability has been proven over the 40 years that it has been in use. The MSQ short form consists of 20 items, which measures two types of job satisfaction, namely intrinsic satisfaction and extrinsic satisfaction. Of these 20 items, 12 items measure intrinsic factors/occupational conditions (ability utilization, achievement, activity, authority, creativity, independence, moral values, responsibility, security, and social status) and extrinsic satisfaction from 8 items. Responses were based on a five-point Likert scale where; 1-Strongly Disagree, and 5-Strongly Agree.

For work volition study scale developed by Duffy et al. [4] has been adopted. There are 11 items that measure an individual's work volition and are rated on a 5-point Likert scale ranging from 1-Strongly Disagree, and 5-Strongly Agree. The scale has been used in various studies with an alpha value of 0.80 [3] [4] [52]. Thus, the scale was found suitable for the present study.

\section{Data Analysis}

For the analysis, AMOS 21 and SPSS software was used. Confirmatory factor analysis (CFA) was used to test whether a relationship between the observed variables and their underlying latent construct(s) exist. According to Suhr [53], an observed variable can be measured directly and known as an indicator, a measured variable, or a manifest variable. On the other hand, a latent construct can be measured indirectly by identifying its influence on responses to measured va- 
riables. A latent construct is also called an unobserved variable, factor, or underlying construct.

CFA using SEM was used to test first- and higher-order factor models. This method depends on several fit indices to determine the adequacy of model-data fit. The chi-square $\left(\chi^{2}\right)$ is the most common index to evaluate the goodness of fit of the model. It measures the difference between expected and observed covariance matrices. The closer the chi-square value is to zero, the better the fit is between the expected and observed covariance matrices [54]. The other indices, including a goodness of fit index (GFI), adjusted goodness of fit index (AGFI), normed fit index (NFI), comparative fit index (CFI), and root mean square error of approximation (RMSEA) are used to assess the model fit. GFI is a measure of the relative amount of variance and covariance accounted for by the whole model [54]. AGFI adjusts the GFI based upon the degree of freedom in the model [55] and NFI compares the $\chi^{2}$ value of the proposed model to the $\chi^{2}$ value of the null model. CFI avoids the underestimation of fit often noted in small samples for NFI [56]. A cut off criterion of 0.90 for these scores (GFI, AGFI, NFI, and CFI) is recommended to indicate evidence of a good fit [56] [57]. However, many researchers interpret index scores above 0.80 to represent a reasonable model fit [54] [58]. The RMSEA tells us how well the model, with unknown but optimally chosen parameter estimates, would fit the population covariance matrix ([59] Byrne and Marsh, 1998). RMSEA values less than 0.06 indicate a good model fit [57]. However, RMSEA values less than 0.08 indicate an adequate model fit [60]. The fit indices and their acceptable thresholds are shown in Table 2.

\section{The Results}

The hypothesized relationships were examined by structural model (see Figure 1 \& Figure 2, Table 3 \& Table 4) using AMOS 21. It is proposed that employees are likely to report higher job satisfaction levels if they have taken up their favorite jobs. Job satisfaction has been used as the dependent variable. The results indicate a significant relationship between work volition and employee job satisfaction in both internal and external job satisfaction $(\beta=0.530, \mathrm{p}<0.05 ; \beta=$ $0.671, \mathrm{p}<0.05$, respectively). These results found support for both the proposed

Table 2. Fit indices and their acceptable thresholds.

\begin{tabular}{cc}
\hline Fit index & Acceptable threshold levels \\
\hline Fit ratio & $3.0[61]$ \\
GFI & Values greater than $0.90[57]$ \\
AFGI & Values greater than $0.90[57]$ \\
NFI & Values greater than $0.90[56]$ \\
CFI & Values greater than $0.90[57]$ \\
RMSEA & Values less than $0.08[60]$ \\
\hline
\end{tabular}




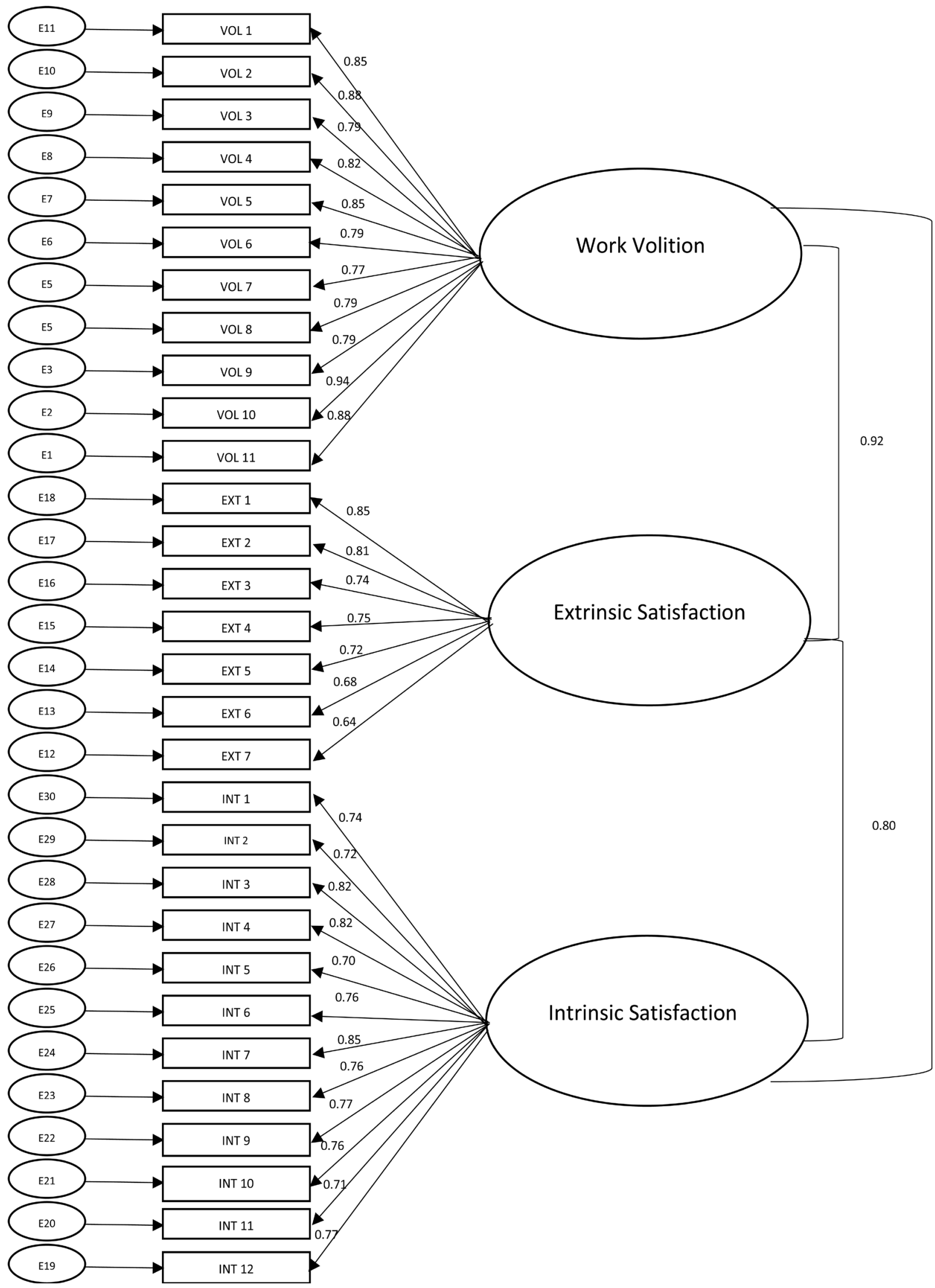

Figure 1. Overall model fit. 


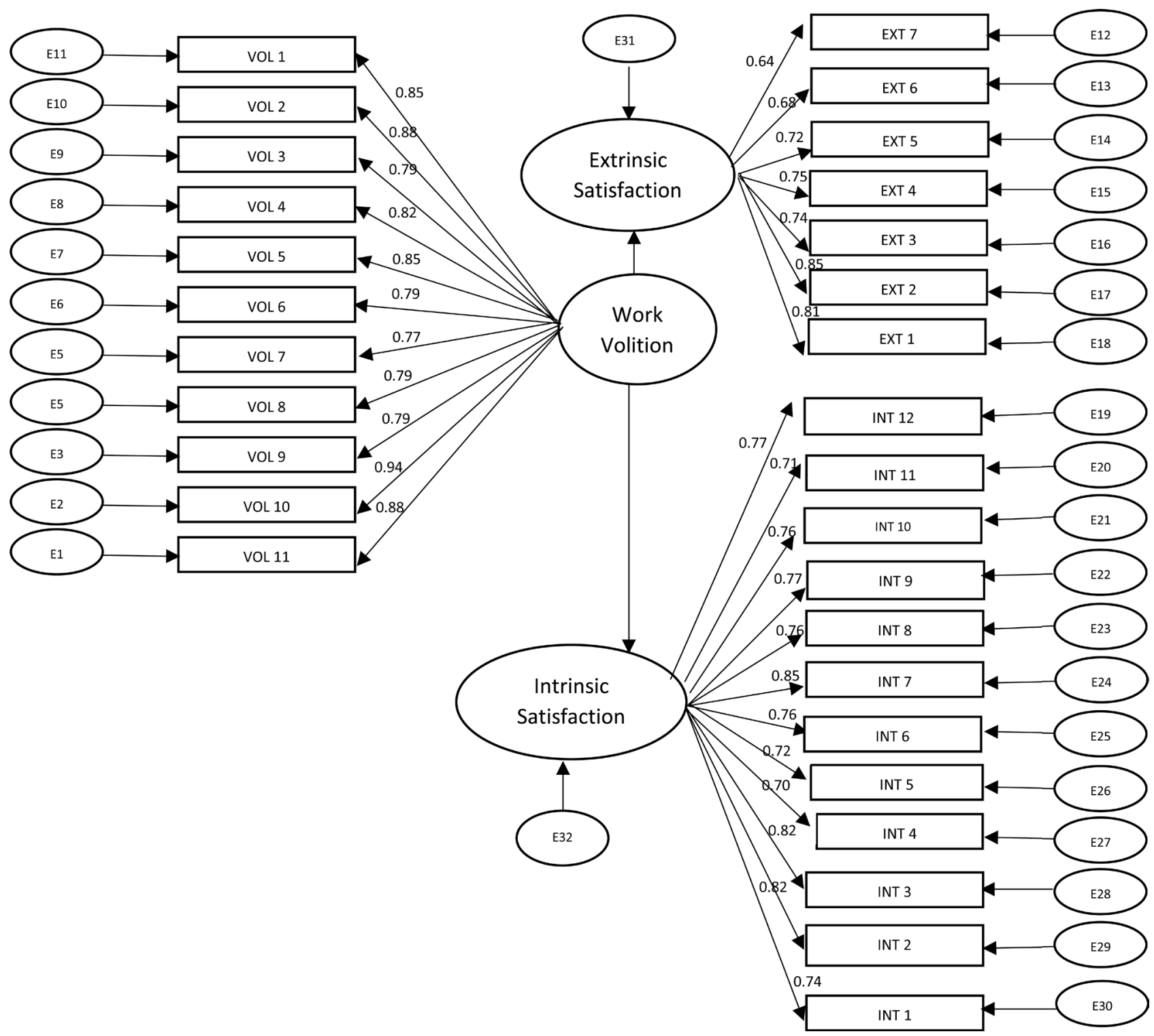

Figure 2. The structural model.

Table 3. Fit Indices of measurement model (CFA).

\begin{tabular}{ccc}
\hline Fit index & Recommended values [53] [57] [62] [63] & Observed values \\
\hline Chi-square & $<3.0$ & 1577.448 \\
Chi-square/df & 0.90 & 3.924 \\
GFI & 0.90 & 0.941 \\
CFI & 0.90 & 0.873 \\
RMSEA & $<0.70$ & 0.063 \\
\hline
\end{tabular}

Table 4. Results of the structural model.

\begin{tabular}{ccccc}
\hline Relationship & Estimates & SE & $\mathrm{t}$ & $\mathrm{p}$ \\
\hline External Satisfaction and Work Volition & 0.530 & 0.050 & 10.62 & $* * *$ \\
Internal Satisfaction and Work Volition & 0.671 & 0.050 & 13.28 & $* * *$ \\
\hline
\end{tabular}


hypotheses. Furthermore, the results demonstrate that work volition can be a useful tool for enhancing employee job satisfaction. Therefore, organizations focused on proper recruitment methods and those endeavoring to provide employees a satisfying career should strive to give its employees the job content closest to their ideal.

The results also indicate a positive impact of work volition on both intrinsic and extrinsic job satisfaction. All the factors of intrinsic and extrinsic job satisfaction were found significantly correlated with work volition. Therefore, to ensure that employees are satisfied, the organizations should provide freedom of choice on kinds and quality of jobs based on employee job preferences [63].

The overall positive correlations also indicate that employee retention as an organizational goal can be better achieved with organizations offering roles consistent with individual likes and preference. Furthermore, a positive correlation was reported across the study samples, further cementing the assumption that work volition has universal appeal at least in the higher education sector in whole of Pakistan. Therefore, the role of choice based careers cannot be emphasized more.

\section{Discussion}

In one of the first studies in Pakistan on impact of work volition on employee job satisfaction with a limited sample size, this study provides credence and credibility to other studies in this domain on significance of work volition on a variety of work related characteristics including job satisfaction. The study was consistent with previous studies that a satisfied employee is more likely to have chosen or stepped on the right job [3] [64] [65] [66]. The results from an underdeveloped country like Pakistan having far more number of job seekers than available jobs, are testimonial of the construct that men would spend a lifetime on jobs they love. A less satisfied but well paid worker is more likely to switch jobs than the one who is well engaged with his work [25] [67] [68] [69]. Hence employee engagement programs designed around work volition can likely yield improved retention figures for the organization.

\section{Limitations and Recommendations for Future Research}

Like every study, this study also had several individual and external limitations and constraints. The first limitation is the size of the sample. The study covered a few higher educational institutes of Pakistan, a larger sample could have added more credibility to the findings. The second limitation is limited diversity. A sample drawn from a more diverse population could have improved the applicability of the findings. Since, results are often influenced by organization type, employees' attitude, and rank in the organization. Finally, this study did not account for cultural variables (e.g. collectivism, and traditionality) or employee attributes (e.g. person-organization fit and person-job fit) on the relationship between organizational justice and organizational commitment. Future studies 
can consider examining the moderating effect of cultural variables on work volition and job satisfaction while studying samples from academic institutes. This study has also opened the door for exploring other relations like work volition and employee retention, work volition and employee engagement programs, work volition and worker loyalty amongst other organizational and human resource studies.

\section{References}

[1] Blustein, D.L. (2006) The Psychology of Working: A New Perspective for Career Development, Counselling and Public Policy. Lawrence Erlbaum Associates, Inc., New Jersey.

[2] Duffy, R.D. and Dik, B.J. (2009) Beyond the Self: External Influences in the Career Development Process. The Career Development Quarterly, 58, 29-43. https://doi.org/10.1002/j.2161-0045.2009.tb00171.x

[3] Duffy, R.D., Bott, E.M., Torrey, C.L. and Webster, G.W (2012) Work Volition as Critical Moderator in the Prediction of Job Satisfaction. Journal of Career Assessment, 21, 20-31. https://doi.org/10.1177/1069072712453831

[4] Duffy, R.D., Diemer, M.A., Perry, J.C., Laurenzi, C. and Torrey, C.L. (2012) The Construction and Initial Validation of the Work Volition Scale. Journal of Vocational Behavior, 80, 400-411. https://doi.org/10.1016/j.jvb.2011.04.002

[5] Gannon, M.J. (1984) Preferences of Temporary Workers: Time, Variety and Flexibility. Monthly Labor Review, 107, 26-28.

[6] Beard, K.M. and Edwards, J.R. (1995) Employees at Risk: Contingent Work and the Psychological Experience of Contingent Workers. In: Cooper, C.I. and Rousseau, D.M., Eds., Trends in Organizational Behavior, Wiley, Oxford, UK, Vol. 2, 109-126.

[7] Krausz, M. (2000) Effects of Short- and Long-Term Preference for Temporary Work upon Psychological Outcomes. International Journal of Manpower, 21, 635-647. https://doi.org/10.1108/01437720010379529

[8] Holtom, B.C., Lee, T.W. and Tidd, S.T. (2002) The Relationship between Work Status and Congruence and Work-Related Attitudes and Behaviors. Journal of Applied Psychology, 87, 903-915. https://doi.org/10.1037/0021-9010.87.5.903

[9] Feldman, D.C. and Turnley, W.H. (2004) Contingent Employment in Academic Careers: Relative Deprivation among Adjunct Faculty. Journal of Vocational Behavior, 64, 284-307. https://doi.org/10.1016/j.jvb.2002.11.003

[10] Duffy, R.D., Allan, B.A., Autin, K.L. and Bott, E.M. (2013) Calling and Life Satisfaction: It's Not about Having It, It's about Living It. Journal of Counseling Psycholo$g y$, 60, 42-52. https://doi.org/10.1037/a0030635

[11] Duffy, R.D., Douglass, R.P. and Autin, K.L. (2015) Career Adaptability and Academic Satisfaction: Examining Work Volition and Self-Efficacy as Mediators. Journal of Vocational Behavior, 90, 46-54. https://doi.org/10.1016/j.jvb.2015.07.007

[12] Willem, A., Buelens, M. and Jonghe, I.D. (2007) Impact of Organizational Structure on Nurses' Job Satisfaction: A Questionnaire Survey. International Journal of Nursing Studies, 44, 1011-1020. https://doi.org/10.1016/j.ijnurstu.2006.03.013

[13] Yang, J. (2009) Antecedents and Consequences of Job Satisfaction in the Hotel Industry. International Journal of Hospitality Management, 29, 609-619. https://doi.org/10.1016/j.ijhm.2009.11.002

[14] Locke, E.A. (1976) The Nature and Causes of Job Satisfaction. Handbook of Indus- 
trial and Organizational Psychology, 1, 1297-1343.

[15] Armstrong, M. (2003) A Handbook of Human Resource Management Practice. $9^{\text {th }}$ Edition, Kogan Page, London.

[16] Odom, R.Y., Boxx, W.R. and Dunn, M. (1990) Organizational Cultures, Commitment, Satisfaction and Cohesion. Public Productivity and Management Review, 14, 157-169. https://doi.org/10.2307/3380963

[17] Ranft, V. and Ranft, A. (1999) Rightsizing the Multi-Divisional Firm: Individual Response to Changes across Divisions. Management, 2, 195-208.

[18] Sweeney, A.P., Hohenshil, T.H. and Fortune, J.C. (2002) Job Satisfaction among Employee Assistance Professionals: A National Study. Journal of Employment Counseling, 39, 50-60. https://doi.org/10.1002/j.2161-1920.2002.tb00837.x

[19] Arnett, D.B., Laverie, D.A. and McLane, C. (2002) Using Job Satisfaction and Pride as Internal-Marketing Tools. Cornell Hotel and Restaurant Administration Quarterly, 43, 87-96. https://doi.org/10.1177/001088040204300209

[20] Tourangeau, A.E. and Cranley, L.A. (2006) Nurse Intention to Remain Employed: Understanding and Strengthening Determinant. Journal of Advanced Nursing, 55, 497-509. https://doi.org/10.1111/j.1365-2648.2006.03934.x

[21] Coomber, B. and Barriball, K.L. (2007) Impact of Job Satisfaction Components on Intent to Leave and Turnover for Hospital-Based Nurses: A Review of the Research Literature. International Journal of Nursing Studies, 44, 297-314. https://doi.org/10.1016/j.ijnurstu.2006.02.004

[22] Robbins, S.P. and Judge, T.A. (2009) Essential of Organizational Behaviour. 10th Edition, Pearson Education, New York.

[23] Kavanaugh, J., Duffy, J.A. and Lilly, J. (2006) The Relationship between Job Satisfaction and Demographic Variables for Healthcare Professionals. Management Research News, 29, 304-325. https://doi.org/10.1108/01409170610683842

[24] Clark, A.E., Oswald, A. and Warr, P. (1996) Is Job Satisfaction u-Shaped in Age? Journal of Occupational and Organizational Psychology, 69, 57-81.

[25] Spector, P. (1997) Job Satisfaction: Application, Assessment, Causes and Consequences. Sage Publications, Thousand Oaks.

[26] Cowin, L.S., Johnson, M., Craven, R.G. and Marsh, H.W. (2008) Causal Modelling of Self-Concept, Job Satisfaction and Retention of Nurses. International Journal of Nursing Studies, 45, 1449-1459. https://doi.org/10.1016/j.ijnurstu.2007.10.009

[27] Brown, S.P. and Peterson, R.A. (1993) Antecedents and Consequences of Salesperson Job Satisfaction: Meta-Analysis and Assessment of Causal Effects. Journal of Marketing Research, 30, 63. https://doi.org/10.2307/3172514

[28] Allen, D.G., Bryant, P.C. and Vardaman, J.M. (2010) Retaining Talent: Replacing Misconceptions with Evidence-Based Strategies. The Academy of Management Perspectives, 24, 48-64.

[29] Chen, G., Ployhart, R.E., Thomas, H.C., Anderson, N. and Bliese, P.D. (2011) The Power of Momentum: A New Model of Dynamic Relationships between Job Satisfaction Change and Turnover Intentions. Academy of Management Journal, 54, 159-181. https://doi.org/10.5465/amj.2011.59215089

[30] Cotton, C. (2008) Examining Public-and-Private-Sector Challenges. WorldatWork Journal, 38-43.

[31] Muchinsky, P.M. and Morrow, P.C. (1980) A Multi-Disciplinary Model of Voluntary Employee Turnover. Journal of Vocational Behavior, 17, 263-290. https://doi.org/10.1016/0001-8791(80)90022-6 
[32] Tett, R.P. and Meyer, J.P. (1993) Job Satisfaction, Organizational Commitment, Turnover Intention, and Turnover: Path Analysis Based on Meta-Analytic Findings. Personnel Psychology, 46, 259-293. https://doi.org/10.1111/j.1744-6570.1993.tb00874.x

[33] Trevor, C. (2001) Interactive Effects among Actual Ease of Movement Determinants and Job Satisfaction in the Prediction of Voluntary Turnover. Academy of Management Journal, 44, 621-638.

[34] Vandenberg, J.R. and Nelson, J.B. (1999) Disaggreatives the Motives Underlying Turnover Intentions: When Do Intentions Predict Turnover Behavior. Human Relations, 52, 1340-1352. https://doi.org/10.1177/001872679905201005

[35] Al-Hussami, M. (2008) A Study of Nurses' Job Satisfaction: The Relationship to Organizational Commitment, Perceived Organizational Support, Transactional Leadership, Transformational Leadership, and Level of Education. European Journal of Science Resource, 22, 286-295.

[36] Herzberg, F., Mausner, B. and Snyderman, B.B. (1959) The Motivation to Work. John Wiley \& Sons, New York.

[37] Furnham, A., Badmin, N. and Sneade, I. (2002) Body Image Dissatisfaction: Gender Differences in Eating Attitudes, Self-Esteem, and Reasons for Exercise. The Journal of Psychology, 136, 581-596. https://doi.org/10.1080/00223980209604820

[38] Greenberg, J. (1999) Managing Behavior in Organizations. 2nd Edition, Prentice-Hall International, Inc., Trenton.

[39] Ellickson. M.C. and Logsdon, K. (2002) Determinants of Job Satisfaction of Municipal Government Employees. Public Personnel Management, 31, 343-358. https://doi.org/10.1177/009102600203100307

[40] Behling, O., Labovitz, G. and Kosmo, R. (1968) The Herzberg Controversy: A Critical Reappraisal. Academy of Management Journal, 11, 99-108.

[41] Shields, J. (2007) Managing Employee Performance and Reward. Cambridge University Press, Melbourne. https://doi.org/10.1017/CBO9781139168748

[42] Gaziel, H. (1986) Correlates of Job Satisfaction: A Study of the Two Factor Theory in an Educational Setting. The Journal of Psychology, 120, 613-626. https://doi.org/10.1080/00223980.1986.9915491

[43] Bolliger, D.U. and Wasilik, O. (2009) Factors Influencing Faculty Satisfaction with Online Teaching and Learning in Higher Education. Distance Education, 30, 103-116. https://doi.org/10.1080/01587910902845949

[44] Sabharwal, M. and Corley, E.A. (2009) Faculty Job Satisfaction across Gender and Discipline. The Social Science Journal, 46, 539-556. https://doi.org/10.1016/j.soscij.2009.04.015

[45] Grace, D.H. and Khalsa, S.A. (2003) Re-Recruiting Faculty and Staff: The Antidote to Today's High Attrition. Independent School, 62, 20-27.

[46] Dee, J.R. (2002) Turnover Intent in an Urban Community College: Strategies for Faculty Retention. Paper Presented at the Annual Meeting of the Association for the Study of Higher Education, Sacramento.

[47] VanderPutten, J. and Wimsatt, L. (1999) Cross-National Faculty Departure: Development of a New Model. Paper Presented at the Annual Meeting of the Association for the Study of Higher Education, San Antonio.

[48] Hamdia, M. and Phadett, T. (2011) Conceptual Framework on the Relationship between Human Resource Management Practices, Job Satisfaction and Turnover. Journal of Economics and Behaviour Studies, 2, 41-49. 
[49] Hagedorn, L.S. (2000) Conceptualizing Faculty Job Satisfaction: Components, Theories, and Outcomes. New Directions for Institutional Research, 105, 5-20. https://doi.org/10.1002/ir.10501

[50] Duffy, R.D., Diemer, M.A. and Jadidian, A. (2012c) The Development and Initial Validation of the Work Volition Scale-Student Version. The Counseling Psychologist, 40, 291-319. https://doi.org/10.1177/0011000011417147

[51] Weiss, D.J., Dawis, R.V., England, G.W. and Lofquist, L.H. (1967) Manual for the Minnesota Satisfaction Questionnaire. Minneapolis. Minnesota Studies in Vocational Rehabilitation, 22, 120.

[52] Duffy, R.D., Bott, E.M., Allan, B.A. and Torrey, C.L. (2013) Examining a Model of Life Satisfaction among Unemployed Adults. Journal of Counselling Psychology, 60, 53-63. https://doi.org/10.1037/a0030771

[53] Suhr, D.D. (2006) Exploratory or Confirmatory Factor Analysis? SAS Institute, Cary, 1-17.

[54] Jöreskog, K.G. and Sörbom, D. (1989) LISREL7: A Guide to the Program and Applications. 2nd Edition, SPSS Inc., Chicago.

[55] Tabachnick, B.G. and Fidell, L.S. (2007) Using Multivariate Statistics. 5th Edition, Allyn and Bacon, New York.

[56] Bentler, P.M. and Bonett, D.G. (1980) Significance Tests and Goodness-of-Fit in the Analysis of Covariance Structures. Psychological Bulletin, 88, 588-600.

https://doi.org/10.1037/0033-2909.88.3.588

[57] Hu, L. and Bentler, P.M. (1999) Cutoff Criteria for Fit Indexes in Covariance Structure Analysis: Conventional Criteria versus New Alternatives. Structural Equation Modeling: A Multidisciplinary Journal, 6, 1-55.

[58] Paulraj, A. (2011) Understanding the Relationships between Internal Resources and Capabilities, Sustainable Supply Management and Organizational Sustainability. Journal of Supply Chain Management, 47, 19-37. https://doi.org/10.1111/j.1745-493X.2010.03212.x

[59] Byrne, B.M. and Marsh, H.W. (1999) "How to Do" Structural Equation Modeling in Lisrel. PsycCRITIQUES, 44, 284-286.

[60] Browne, M.W. and Cudeck, R. (1993) Alternative Ways of Assessing Model Fit. In: Bollen, K.A. and Long, J.S., Eds., Testing Structural Equation Models, Sage, Beverly Hills, 136-162.

[61] Bagozzi, R.P., Yi, Y. and Nassen, K.D. (1998) Representation of Measurement Error in Marketing Variables: Review of Approaches and Extension to Three-Facet Designs. Journal of Econometrics, 89, 393-421. https://doi.org/10.1016/S0304-4076(98)00068-2

[62] Malhotra, N.K. and Dash, S. (2011) Marketing Research: An Applied Orientation. 6th Edition, Pearson Education, New York.

[63] Hair, F.J., Sarstedt, M., Hopkins, L.G. and Kuppelwieser, V. (2014) Partial Least Squares Structural Equation Modeling (PLS-SEM): An Emerging Tool in Business Research. European Business Review, 26, 106-121.

[64] Boshoff, C. and Allen, J. (2000) The Influence of Selected Antecedents on Frontline Staff's Perceptions of Service Recovery Performance. International Journal of Service Industry Management, 11, 63-90. https://doi.org/10.1108/09564230010310295

[65] Saari, L.M. and Judge, T.A. (2004) Employee Attitudes and Job Satisfaction. Human Resource Management, 43, 395-407. https://doi.org/10.1002/hrm.20032

[66] Lumley, E.J., Coetzee, M., Tladinyane, R. and Ferreira, N. (2011) Exploring the Job 
Satisfaction and Organisational Commitment of Employees in the Information Technology Environment. Southern African Business Review, 15, 100-118.

[67] Kwon, I. and Sohn, K. (2017) Job Dissatisfaction of the Self-Employed in Indonesia. Small Business Economics, 49, 233-249. https://doi.org/10.1007/s11187-016-9820-Z

[68] Zablah, A.R., Carlson, B.D., Donavan, D.T., Maxham III, J.G. and Brown, T.J. (2016) A Cross-Lagged Test of the Association between Customer Satisfaction and Employee Job Satisfaction in a Relational Context. Journal of Applied Psychology, 101, 743. https://doi.org/10.1037/apl0000079

[69] Millán, J.M., Hessels, J., Thurik, R. and Aguado, R. (2013) Determinants of Job Satisfaction: A European Comparison of Self-Employed and Paid Employees. Small Business Economics, 40, 651-670. https://doi.org/10.1007/s11187-011-9380-1 